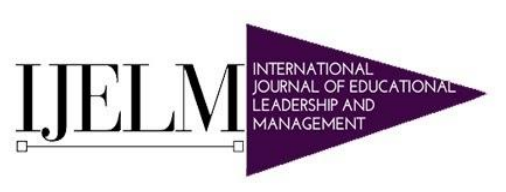

Hipatia Press

www.hipatiapress.com

Instructions for authors, subscriptions and further details:

http://ijelm.hipatiapress.com

\title{
School Principal Support in Teacher Professional Development
}

Mehmet Fatih Karacabey ${ }^{1}$

1) Harran University, Turkey.

Date of publication: January $16^{\text {th }}, 2021$

Edition period: July 2020 - January 2021

To cite this article: Fatih, M. (2021). School Principal Support in Teacher Professional Development. International Journal of Educational Leadership and Management.

doi: $10.17583 /$ ijelm.2020.5158

To link this article: http://dx.doi.org/10.17583/ijelm.2020.5158

PLEASE SCROLL DOWN FOR ARTICLE

The terms and conditions of use are related to the Open Journal System and to Creative Commons Attribution License (CCAL). 


\title{
School Principal Support in Teacher Professional Development
}

\author{
Mehmet Fatih Karacabey \\ Harran University \\ Turkey
}

\begin{abstract}
Turkish education system has enacted a vision of 2023 which emphasizes that school principals create and organize professional learning activities based on the needs of students and teachers. This research aimed to evaluate this vision by determining the level of support provided by school principals in teachers' professional development. It was based on a cross-sectional survey design of the quantitative method. The data collected from the 4,729 teachers working in Sanliurfa province in Turkey were analyzed. The results suggested that the school principals supported the professional development of the teachers occasionally and only $25.5 \%$ of principals supported teachers' professional development sufficiently. School principals mostly followed relevant resources to support teachers' professional development and inform teachers about innovations related to education. In addition, school principals did not adequately perform activities that may support teacher professional development such as determining individual and group development programs, organizing a professional development monitoring form for teachers, organizing educational activities outside the seminar period, receiving enough help from the experts in the area, and giving enough individual reading and research tasks. The results also indicated that the principals of high school teachers supported their professional development more than the principals working in primary and secondary schools, the principals of the classroom teachers and the principals of male teachers supported the professional development of the teachers more than the principals of the female and branch teachers and teachers' level of education did not create any difference in the perceptions of the teachers.
\end{abstract}

Keywords: Teacher professional development, personnel development, in-service education, school principal. 


\title{
El apoyo del director escolar en el desarrollo profesional de los docentes
}

\author{
Mehmet Fatih Karacabey \\ Harran University \\ Turkey
}

\section{Resumen}

El sistema educativo turco ha promulgado una visión de 2023 que enfatiza que los directores de las escuelas creen y organizen actividades de aprendizaje profesional basadas en las necesidades de los estudiantes y maestros. Este estudio tiene como objetivo evaluar esta visión determinando el nivel de apoyo brindado por los directores de las escuelas en el desarrollo profesional de los maestros. Se basó en un diseño de encuesta transversal del método cuantitativo. Se analizaron los datos de 4.729 docentes de la provincia de Sanliurfa (Turquía). Los resultados manifiestan que los directores de las escuelas apoyan el desarrollo profesional de los maestros ocasionalmente y solo el $25.5 \%$ de los directores apoyaban suficientemente el desarrollo. Los directores de las escuelas en su mayoría tienen recursos para apoyar el desarrollo profesional de los docentes e informarles sobre las innovaciones relacionadas con la educación. Además, los directores de las escuelas no realizan actividades que pueden apoyar el desarrollo profesional de los docentes, como determinar programas de desarrollo individual y grupal, formulario de seguimiento del desarrollo profesional, organizar actividades educativas fuera del período del seminario, recibir ayuda de los expertos en el área, y dando suficientes tareas individuales de lectura e investigación. Los resultados afirman que los directores de los profesores de secundaria apoyan su desarrollo profesional más que los directores que trabajan en las escuelas primarias, los directores de los maestros de aula y los directores de los maestros hombres apoyan el desarrollo profesional de los maestros más que los directores de las maestras. La rama educativa de los maestros y el nivel de educación de los maestros no crea ninguna diferencia en las percepciones de los maestros.

Palabras clave: Desarrollo profesional docente, desarrollo de personal, educación en el servicio, director de escuela. 
W Ith the growing pressure on schools and principals to improve student learning outcomes as a result of accountability policies in many countries, the idea of principals supporting teacher learning has received substantial attention from the scholars in the field of Educational Management and Leadership (EDLM) (Liu, Hallinger \& Feng, 2016). Principals have been overwhelmingly expected to improve teaching and learning activities in their schools. They are now required to create and support a school environment in which teachers enhance their knowledge and practices in order to ensure the learning of all students (Duffield, Wageman, \& Hodge, 2013).

Teacher professional development involves all learning opportunities that enable teachers to adapt to changes in the education system and increase their effectiveness (Smith \& Gillespie, 2007). In this age when the success of the education system was evaluated with the success of the students, it was determined that the teachers had a significant effect on the success of the students (Buchanan, 2012; Rushton, Morgan \& Richard, 2007; Scheerens, 2010). The research showed that teacher professional development indirectly increases student achievement by increasing teachers' effectiveness (Duffield et al.,2013). While teachers themselves are responsible for their professional development, school principals are the leaders who provide opportunities to support teachers' professional development.

There has been an increasing interest in the idea of school leaders promoting teacher professional development in Turkey as well. Previous research indicated that school principals did not fulfill these duties adequately (Bozkuş, 2016; Çalık \& Şehitoğlu, 2006). It is stated that there are many problems in the pre-service training provided for the training of teachers (Aypay, 2009). Therefore, teachers in Turkey, subject areas, in pedagogy, it is determined that they have deficiencies in professional satisfaction and appreciation of the visual field (Uçar, 2011). However, it is stated that teachers do not attempt to improve themselves professionally (Abazaoğlu, Yıldırım, \& Y1ldizhan, 2014). School administrators also state that teachers do not care about professional development (Turan, Y1ldırım, \& Aydoğdu, 2012). Although encouraging teachers to be trained in their professions is considered 
among the duties of school administrators (Gündüz \& Balyer, 2013), teachers do not find the level of administrators to fulfill their professional development tasks (Bakioğlu \& İnand1, 2001). Therefore, Turkey has recently been undergoing an intense educational reform movement that attaches considerable value to the workplace teacher professional learning. The country's 2023 vision that guides the reform movement emphasizes that school principals create and organize professional learning activities based on the needs of students and teachers. While the debate regarding the reform and its potential outcomes is considerable, it is important to make a better sense of current practices of principals in supporting teacher professional learning and associated problems in order to provide recommendations that guide the implementation of reforms. The purpose of this study is, therefore, to determine how and to what extent principals provide support for teacher learning in Turkish schools depending on teachers' perceptions. For this purpose, the following questions were answered:

RQ1. What activities do school principals use to support the professional development of teachers?

RQ2. What is the level of school principals 'support for teachers' professional development?

RQ3. What is the percentage of school principals that adequately support teacher professional development?

RQ4. Do teachers' perceptions of principals support for professional learning vary by teachers' gender, level of education and branch, as well as school level? 


\section{Literature Review}

\section{Professional Develoment}

Although there is more than one definition in the literature, it is possible to summarize the professional development process as the period in which the professional evaluates, increases or renews his responsibilities and acquires knowledge and skills by interacting with his environment during this stage. Professional development means growth and development without focusing on a specific task (Hardy, 2012). It has emerged from several concepts including the continuation of vocational training, self-improvement, inservice training, and career development in order to be more successful and productive in the profession while people are working. It has become a very important concept in every sector today. Competition necessitates professional development (Swart, Knèzic, Onstenk \& Graaff, 2019). The situation is not different for teachers (Elçiçek, 2016).

Professional development, which covers all the processes that support the development of professional skills and knowledge, is the process of selfrenewal by adapting to changing technology and living conditions throughout one's life. Odabaşı (2011) defines the concept of professional development as systematic studies carried out in order to increase the effectiveness and skills of professionals in their jobs.

Ekinci (2015) argues that the competence of people in their professions can only be increased through professional development and argues that it is possible to observe and eliminate the problems that arise from other people in the same occupational group through professional development. The quality of the work varies according to the professional development opportunities of the employee and ensures that the employee and his / her environment are always open to new knowledge and experience. It has become a turning point in people's lives because it helps people discover and eliminate their missing aspects in their occupations (K1z1lkaya, 2012). 


\section{Teacher Professional Development}

Raising the welfare of society and directing people to areas such as science, arts, social, cultural and economic development is possible with high quality, age-appropriate, modern and individual-specific education, and the role of teachers is key. It is, therefore, no coincidence that states that produce sustainable policies for teachers are developed and strong in many areas. Societies can be productive in agriculture, medicine, arts, economics and other disciplines through teachers who constantly develop themselves in the professional field and those who directly adopt lifelong learning (Elçiçek, 2016).

Odabaş1 (2011) states that the professional development of teachers is to constantly update their knowledge, skills, and attitudes in the subject area, instructional, managerial and personal area of the teacher. Day (1999) states that the main purpose of the professional development of teachers is to increase the effectiveness in the classroom. This feature is one of the most important features that distinguishes professional development from the professional development of other professionals in the teaching profession. The author states that the teacher will acquire a natural teaching ability by developing himself/herself professionally and can create an education system in all activities in the classroom. Games, stories and collective activities will both entertain and socialize students and improve their learning processes and abilities.

Professional development must be systematically addressed, especially in the case of teachers. This is because the teacher is the person practicing. The teacher should not try new training techniques and current issues without internalizing them (Kennedy, 2016). If s/he does, it may not achieve the targeted efficiency at school. Furthermore, the support of lifelong learning and professional development by the educational institution in which it is located may facilitate the teacher to take steps in this regard (Gürer, 2017; Kiz1lkaya, 2012).

The environment is very important for the professional development of teachers. Because the teaching profession is multifaceted. The teacher should 
be able to recognize his students easily, to discover their talents and tendencies, to gather information about family life, to teach the lessons and to carry out many tasks at the same time (Akiba \& Liang, 2016). Therefore, it is essential that professional development is carried out under the influence of many disciplines (Bowe \& Gore, 2017). It is very important for teachers to have environments where they can perform many activities for the development of both students and teachers (OECD, 2009). Education is a discipline in which new methods are continuously developed and knowledge is continuously increased (Stentoft, 2017). This situation forces teachers to stay up to date. In schools, administrators, education policies, educational materials and other physical conditions of the school should be in a structure to support professional development (Djatmiko, 2010).

However, it should be remembered that the teacher should also be willing about professional development (Bozkuş \& Taştan, 2016). Because, informally, professional development must continue. This is called out-ofschool professional development. Such professional development is carried out through various courses, seminars, and practices. Furthermore, teachers need to be careful when choosing such professional development opportunities. It is important for them to participate in training and seminars by organizations such as approved institutions and universities and in areas where development needs are needed, in order to achieve efficiency. Preferred professional development activities should be aimed at meeting needs (Özer, 2008).

\section{Importance of Teacher Professional Development}

The development of teachers directly affects the development of society. A self-improving teacher can have students who learn better and faster, enjoy learning, and are up to date. In addition, the teacher's commitment and enthusiasm for learning will serve as an example for her students and can pave the way for students to become self-improved. By experimenting with new methods, students begin to explore both themselves and the world, and a dynamic society can be created by transforming the actions taken to develop into habits (Özdemir, 2016). 
Professional development actually means that adults continue their education. This is a lifelong process based on experiential and theoretical methods. Teachers distinguish themselves from other occupational groups in the community in developing their profession (Vangrieken, Meredith, Packer \& Kyndt, 2017). Because teaching is a profession in which constantly changing, developing and renewed knowledge is gained (Lysaght, O'Leary \& Ludlow, 2017). Teachers also need to explore their own abilities to be more successful in their profession. A teacher's interaction with his / her students in line with his / her tendencies allows him to raise successful new generations in this area, while his / her tendencies and abilities are constantly improving. There is no limit to professional development as there is no limit to success. Since adult teachers develop their communication skills within their professional development systems, they are provided to continuously develop each other in schools and social settings. An individual who develops himself naturally exchanges ideas with his environment and encourages others to think and develop (Elçiçek, 2016).

The professional development of teachers will ensure the development of society. Teachers who constantly improve themselves bring about the development of all stakeholders in society. The enthusiasm for learning by teachers and school administrators can help make the student and those in contact with them more open to learning.

\section{The Role of School Administrators in Teacher Professional Development}

School administrators are among those who regulate the working environment of teachers and other school workers. In addition to performing budgetary checks to establish the physical conditions of the school, the administrators also act as bridges between teachers, educational policies, parent-teacher association, parents and other stakeholders of the school. For this reason, the attitude of the managers and their efforts towards professional development can increase the motivation and opportunities of the teachers. Teachers need the support of school administrators to try out the new generation of teaching styles they have learned and to perform various activities with the students. The opinions of school administrators about professional development, the belief in it and the value they attach to 
professional development may play a role in shaping teachers' attitudes (İlğan, 2013).

The openness of school principals to innovations will provide an opportunity for teachers to try new methods they have learned during their professional development process. Teachers will be able to obtain permission from school administrators or support them to create resources and environments. In addition, the value attributed to professional development by school administrators can play a motivating role for teachers to pay more attention to the subject. School administrators will follow the activities that will develop teachers and make announcements about the opportunities and teachers will be able to participate in activities such as seminars and courses. They will also feel the support of the principal and other teachers in doing so (Sabuncuoğlu, 2006; Gözler \& Özmen, 2008).

Teachers' desire to improve themselves in their profession will mean that they will continue to do research by accepting their students. Reading from various sources, preparation of reports, a compilation of articles will contribute to gain the opinions of other researchers in their professional development process.

School administrators are also able to support teachers in finding and researching resources. Certainly, activities such as subscribing to academic journals, supporting teachers to participate in articles and similar competitions among teachers, pointing out where they can reach new research may enable them to learn more about their profession.

It is also important that school principals have leadership characteristics. They can help teachers develop themselves in the professional field if they understand their strengths and weaknesses by following their needs, abilities, and tendencies. For example, if a teacher's social relations with students are not sufficient, the assignment of that teacher in social and cultural activities in the school may strengthen the teacher and his / her relations in this regard. However, it is also important to be able to help an experienced teacher to provide guidance to that teacher. Thus, the interaction between teachers is 
increased and new experiences can be shared at the same time (Korkmaz, 2015; Gürbüz, Erdem \& Y1ldırım, 2013).

School principals have a lot of burden on them while doing their jobs. For this reason, it may mean that teachers evaluate opportunities for their professional development, train assistants, in the short term and facilitate the division of labor. It is possible for teachers to discover their own skills in subjects such as management, leadership, communication, and may start to act as bridges between the principal, school environment, parents and students. In addition, teachers will be able to do both fun and supportive work for developers and managers, such as researching activity opportunities and informing other teachers about them. This will create a communication channel between teachers and administrators (Gürbüz, Erdem \& Yildırım, 2013).

\section{Methods}

The present research is based on a cross-sectional survey design of the quantitative method. This section provides a description of the sample, instrument data collection and analysis.

\section{Sample and Data Collection}

The population of the research consists of 25,734 teachers working in Sanliurfa province in Turkey during the 2017-2018 academic year. This population was selected because of its distinctive features. Teachers in the province are generally inexperienced, young and wanting to move to other provinces. Therefore, they should be prone to problems. All teachers were reached without sampling. Schools were sent a link to an online form on the computer and teachers were invited to participate in the research. The data collected from 4,729 volunteer teachers were analyzed. The form return rate was calculated as approximately $18 \%$. The descriptive statistics of the participants are presented in Table 1. 
Samul - The Research Topics of Leadership: Bibliometric Analysis

Table 1. Participants

\begin{tabular}{cccc}
\hline Variable & Category & $\begin{array}{c}\text { Frequency } \\
\text { (f) }\end{array}$ & $\begin{array}{c}\text { Percentage } \\
\text { (\%) }\end{array}$ \\
\hline \multirow{2}{*}{ Gender } & Male & 2151 & 45.5 \\
& Female & 2578 & 54.5 \\
\hline \multirow{3}{*}{ School Type } & Pre-School & 140 & 3.0 \\
& Primary & 1371 & 29.0 \\
& Secondary & 1954 & 41.3 \\
& High School & 1264 & 26.7 \\
\hline \multirow{2}{*}{ Education Level } & Bachelor's & 4407 & 93.2 \\
& Graduate & 322 & 6.8 \\
\hline \multirow{2}{*}{ Branch } & Pre-School & 309 & 6.5 \\
& Classroom & 1093 & 23.1 \\
& Other & 3327 & 70.4 \\
\hline
\end{tabular}

\section{Instrument}

The online form included questions regarding the demographic characteristics of the participants and teacher professional development scale developed by Bozkuş (2016). There are 10 five-point Likert-rated items in the scale. The construct validity of the scale was established by exploratory and confirmatory factor analyses and $67.3 \%$ of the total variance was explained by a single factor (Bozkuş, 2016). Cronbach's alpha reliability was calculated as $\alpha=0.95$. The confirmatory factor analysis based on the maximum likelihood calculation was performed, and the construct validity was reverified $(\mathrm{X} 2 / \mathrm{df}=47.65, \mathrm{p}<0.001, \mathrm{AGFI}=0.93, \mathrm{GFI}=0.96, \mathrm{CFI}=0.95, \mathrm{NFI}$ $=0.95, \mathrm{IFI}=0.95, \mathrm{RFI}=0.93, \mathrm{RMSEA}=0.09, \mathrm{SRMR}=0.03)$. Since the X2 /df statistic, which is found to be significant and high, is sensitive to the size of the number of participants (Bentler \& Bonnet, 1980; Jöreskog \& Sörbom, 1993), and since the consistency discrimination is low (Kenny \& McCoach, 2003), other indices are accepted as criteria (Hooper, Coughlan \& Mullen, 2008). The adjusted mean-variance developed by Fornell and Larcker (1981) regarding compliance validity was calculated as AVE $=0.68$. Since the AVE value is solid, it is sufficient to be 0.50 and above (Fornell \& Larcker, 1981). Factor loads of the items ranged from 0.71 to 0.90 . 


\section{Data Analysis}

In line with research questions, first, the data analysis started with the descriptive statistics (mean and standard deviation) of the scale items. Second, the percentage of teacher responses were provided to determine school principals' support for teachers' professional development. Finally, inferential statistics (t-test and ANOVA) was carried out to estimate the variation in teachers' responses by their gender, educational level, branch as well as school level.

\section{Results}

The activities of the principals to support the professional development of teachers were determined by calculating the average of the scale items. The mean and standard deviation statistics for the items are presented in Table 2.

\section{Table 2. Mean and Standard Deviation Statistics of Items}

\begin{tabular}{lcc}
\hline Items & $\overline{\boldsymbol{X}}$ & SD \\
\hline $\begin{array}{l}\text { Our school principal follows the relevant resources and informs us about innovations in } \\
\text { education and training }\end{array}$ & 3.43 & 1.24 \\
$\begin{array}{l}\text { Our school principal encourages us to } \quad \text { participate in national congresses, courses and } \\
\text { competitions. }\end{array}$ & 2.99 & 1.31 \\
Our school principal meets with us one-on-one to discuss our strengths and weaknesses & 2.85 & 1.30 \\
Our school principal creates environments where we can share what we have learned & 2.76 & 1.28 \\
Our school principal gives us individual reading and research tasks & 2.59 & 1.16 \\
Our headmaster receives assistance from local experts for professional development & 2.48 & 1.22 \\
Our school principal organizes training activities outside theseminar period for our professional & 2.46 & 1.20 \\
development. & 2.43 \\
Our school principal organizes a professional development monitoring form for each of us & 1.22 \\
Our school head determines individual and group development programs & 2.40 \\
Our school principal performs a sample lesson to improve us & 2.22 \\
\hline Total & 2.06 & 1.18 \\
\hline
\end{tabular}

According to teachers' perceptions, school principals mostly follow relevant resources in order to support the professional development of teachers and inform them about the innovations related to education and training $(X=3.43, S D=1.24)$. Least preferred activity by school principals is to teach sample lessons $(X=2.06, S D=1.18)$. The average of all items $(X=$ 
$2.64, \mathrm{SD}=1.04)$ corresponds to the "sometimes" frequency according to fivepoint Likert intervals (none: 1.00-1.79, rarely: 1.80-2.59, sometimes: 2.60 3.39, often: 3.40-4.19, always: 4.20-5.00).

Table 3. Percentage of School Principals to Support Teachers' Professional Development

\begin{tabular}{llll}
\hline Level & f & $\boldsymbol{\%}$ & $\begin{array}{l}\text { Cumulative } \\
\mathbf{\%}\end{array}$ \\
\hline None & 1124 & 23.8 & 23.8 \\
Rarely & 1126 & 23.8 & 47.6 \\
Sometimes & 1274 & 26.9 & 74.5 \\
Often & 791 & 16.7 & 91.2 \\
Always & 414 & 8.8 & 100.0 \\
\hline Total & $\mathbf{4 7 2 9}$ & $\mathbf{1 0 0 . 0}$ & \\
\hline
\end{tabular}

According to the findings, almost a quarter of teachers think that principals did not support their professional development and another quarter of teachers think that principals rarely support their professional development. The other quarter of teachers think that principals sometimes support their professional development. The remaining teachers think that principals support their professional development. Therefore, $25.5 \%(16.7+8.8)$ of school principals in Sanliurfa support the professional development of teachers frequently and always levels which may be considered as sufficient.

Since the assumption of normality was achieved, independent groups t-test and one-way analysis of variance were used to determine differences in teachers' perceptions regarding the support of teacher professional development by school principals according to demographic variables. Levene's test results indicate that the homogeneity of variance is explored. The findings are presented in Table 4. 
Table 4. Differences by Demographic Variables

\begin{tabular}{|c|c|c|c|c|c|c|c|}
\hline Variable & Category & $n$ & $\bar{X}$ & $S D$ & $T / F$ & $p$ & Difference \\
\hline \multirow{7}{*}{$\begin{array}{r}\text { School } \\
\text { Type }\end{array}$} & 1. Pre- & 140 & 2.72 & 0.93 & \multirow{7}{*}{4.52} & \multirow{7}{*}{$.004^{*}$} & \multirow{7}{*}{$\begin{array}{l}4>2 \\
4>3\end{array}$} \\
\hline & School & & & & & & \\
\hline & 2. Primary & 1371 & 2.57 & 1.05 & & & \\
\hline & 3. & 1954 & 2.64 & 1.04 & & & \\
\hline & Secondary & & & & & & \\
\hline & 4. High & 1264 & 2.71 & 1.04 & & & \\
\hline & School & & & & & & \\
\hline \multirow{3}{*}{$\begin{array}{r}\text { Education } \\
\text { Level }\end{array}$} & 1. & 4407 & 2.64 & 1.04 & \multirow{3}{*}{0.62} & \multirow{3}{*}{.536} & \multirow{3}{*}{ - } \\
\hline & Bachelor's & & & & & & \\
\hline & $\begin{array}{l}2 . \\
\text { Graduate }\end{array}$ & 322 & 2.60 & 1.03 & & & \\
\hline \multirow{5}{*}{ Branch } & 1. Other & 3327 & 2.67 & 1.04 & \multirow{5}{*}{3.95} & \multirow{5}{*}{$.019^{*}$} & \multirow{5}{*}{$1>3$} \\
\hline & 2. Pre- & 309 & 2.58 & 1.04 & & & \\
\hline & School & & & & & & \\
\hline & & 1093 & 2.57 & 1.05 & & & \\
\hline & Classroom & & & & & & \\
\hline \multirow{2}{*}{ Gender } & 1. Male & 2151 & 2.76 & 1.05 & \multirow{2}{*}{7.11} & \multirow{2}{*}{$.000^{* *}$} & \multirow{2}{*}{$1>2$} \\
\hline & 2. Female & 2578 & 2.54 & 1.02 & & & \\
\hline
\end{tabular}

${ }^{*} p<0.05, * * p<0.001$

In the support of teacher professional development, there was a difference in the perceptions of teachers according to school types. When the source of the difference was investigated by the LSD technique, it was found that high school teachers had higher perceptions than primary and secondary school teachers. Therefore, according to the perceptions of teachers, it can be said that the high school principals support the professional development of the teachers more than the primary and secondary school principals.

There was no difference in perceptions of the teachers about principals' supporting their professional development according to teachers' level of education. Therefore, it can be argued that being a graduate of undergraduate or graduate education does not make a difference in teachers' perceptions.

In the support of teacher professional development, perceptions differ according to the branches of teachers. When the source of the difference was 
investigated by the LSD technique, it was determined that branch teachers had higher perceptions than classroom teachers. Therefore, it can be said that the principals of branch teachers support teacher professional development more than classroom teachers' principals.

In the principals' support of teacher professional development, there was a difference in teachers' perceptions according to the gender of the teachers. The reason for the difference was determined that male teachers had higher perceptions than female teachers.

\section{Discussion, Conclusion and Recommendations}

The results of this research suggest that the school principals mostly follow relevant resources to support the professional development of the teachers and inform the teachers about the innovations related to education. Providing teachers with resources to develop their knowledge is considered an important means of professional learning (Gündüz \& Balyer, 2013). However, there is a lack of data to let us know what types of resources are available to principals so that they can support teacher learning. Future research should focus on this issue by investigating resources and materials that could be used for schoolbased professional learning activities. The future research may also concern with the quality of such materials and resources in support of establishing a workplace professional learning community.

It was determined that school principals did not adequately determine individual and group development programs to provide teachers' professional development, did not organize professional development monitoring forms for teachers, did not organize educational activities outside the seminar period, did not receive enough assistance from the surrounding experts and did not assign individual reading and research tasks adequately. All these activities provide teachers with opportunities for professional development. Professional development monitoring forms are tools for identifying teachers' professional development performances and identifying deficiencies and actions (Imhof \& Picard, 2009; Smith \& Tillema, 2001). The professional development of teachers is too extensive to fit into the seminar periods (Can, 
2004). It should continue throughout the whole academic year. School principals should take responsibility for this (Bakioglu \& Inand, 2001). Principals should ensure that teachers employ plans to develop themselves professionally (Bozkuş \& Bayrak, 2019). Why school principals do not apply to these activities should be investigated and measures should be taken according to the results. School principals should be incentivized to apply to professional development activities. Also, their work-load should be lowered to allow them to attend these activities. School principals should be provided with tools to support teacher professional development (Bozkuş, 2019).

In Şanlıurfa province, school principals sometimes support teachers' professional development. In addition, 25.5\% of the principals support the professional development of teachers at sufficient levels. This result is very similar to the previous study using the same data collection tool (Bozkuş, 2016). In other studies (Çalık \& Şehitoğlu, 2006; Ekinci, 2010), it has been shown that school principals do not adequately support the professional development of teachers. In Turkey, the $24 \%$ participation rate of teachers 'professional development, which is quite close to the results of this research, teachers' professional development raises the possibility that they do not turn to their own efforts (MEB, 2016). In addition, the fact that teachers' participation rate in vocational development is approximately twice as high as $51 \%$ in OECD countries requires action on this issue (MEB, 2016). Why school principals do not adequately support teachers' professional development should be discussed with principals and measures should be taken according to the results. Principals should be encouraged to engage in professional development and support teachers in this respect.

According to the perceptions of teachers, it was determined that principals working in a high school supported the professional development of teachers more than primary and secondary school principals. Branch teachers' principals support teachers' professional development more than classroom teachers' principals. These results seem to be contradicting the extant research conducted in the Western world (Gedik \& Bellibas, 2015). Qualitative research is needed to examine why middle and high school principals are likely to provide professional development for teachers. In addition, the results indicated that male teachers have a more positive view of their 
principals' support for professional development than female teachers. Although it is not easy to make an argument for why this is the case, the fact that male principals outnumber their female peers could explain this to some extent. The reason for these differences could further be investigated by qualitative research.

The least activity of the principals is to provide sample lessons. In Turkey, teaching is not effective enough to improve student achievement according to the results of international tests (OECD, 2014; World Bank, 2011). However, teacher's classroom behaviors are an important factor in student success (Creemers, Kyriakides \& Antoniou, 2013; Kyriakides, Campbell \& Gagatsis, 2000; Muijs \& Reynolds, 2000). It is worrying that school principals are not exemplary in teaching lessons to teachers. School principals should teach sample courses more frequently to ensure the professional development of teachers. Thus, if the teachers' classroom behaviors can be improved, it will be possible to increase student achievement (Guskey, 2002; Richard \& Bélanger, 2018). It is therefore recommended that principals should have the content knowledge of subject areas, and they should make sense of how student learn, how teachers teach and how teachers learn to teach, in order to provide necessary support for sample lessons (Stein \& Nelson, 2003), If the reform movement of Turkey is to become successful, there is a need to train school principals in a way that support their knowledge and skills in promoting teaching.

\section{References}

Abazaoğlu, İ., Yıldırım, O. \& Yıldızhan, Y. (2014). Türkiyenin öğretmen profili [Teacher profile of Turkey.]. Turkish Studies, 9(2), 1-20.

Akiba, M., \& Liang, G. (2016). Effects of teacher professional learning activities on student achievement growth. The Journal of Educational Research, 109(1), 99-110.

Aypay, A. (2009). Öğretmenlerin hizmet öncesi öğretmenlik eğitimlerini değerlendirmeleri [Teachers' evaluation of pre-service teacher education]. Kuram ve Uygulamada Eğitim Bilimleri[Education Management in Theory and Practice], 9(3), 1113-1123. 
Bakioğlu, A. \& İnandı, Y. (2001). Öğretmenin kariyer gelişiminde müdürün görevleri [Duties of the principal in the career development of the teacher]. Kuram ve Uygulamada Eğitim Yönetimi [Education Management in Theory and Practice ], 28, 513-529.

Bentler, P. M. \& Bonnet, D. C. (1980). Significance tests and goodness of fit in the analysis of covariance structures. Psychological Bulletin, 88(3), 588-606.

Bowe, J., \& Gore, J. (2017). Reassembling teacher professional development: The case for Quality Teaching Rounds. Teachers and Teaching, 23(3), 352-366.

Bozkuş, K. (2016). Okul müdürlerinin öğretmenlerin mesleki gelişimini sağlama düzeyi [The level of school principals' professional development of teachers]. 8. Uluslararası Eğitim Araştırmaları Kongresi [8th International Educational Research Congress], Çanakkale, Türkiye.

Bozkuş, K. (2019). The teacher professional development student assessment scale: A tool for principals. Research in Educational Administration \& Leadership (REAL), 4(2), 375-405. doi: 10.30828/real/2019.2.6

Bozkuş, K., \& Bayrak, C. (2019). The application of the dynamic teacher professional development through experimental action research. International Electronic Journal of Elementary Education, 11(4), 335-352. doi: 10.26822/iejee.2019450792

Bozkuş, K., \& Taştan, M. (2016). Teacher opinions about qualities of effective teaching. Pegem Ĕgitim ve Ögretim Dergisi, 6(4), 469-490. doi: 10.14527/pegegog.2016.023.

Buchanan, J. (2012). Improving the quality of teaching and learning: A teacher-as-learner centred approach. International Journal of Learning, 18(10), 345-356.

Can, N. (2004). Öğretmenlerin geliştirilmesi ve etkili öğretmen davranışları [Development of teachers and effective teacher behavior]. Erciyes Üniversitesi Sosyal Bilimler Enstitüsü Dergisi [Journal of Social Sciences Institute of Erciyes University], 16(1), 103-119.

Creemers, B., Kyriakides, L. \& Antoniou, P. (2013). Teacher professional development for improving quality of teaching. Dordrecht, Netherlands: Springer.

Çalık, C. \& Şehitoğlu, E. T. (2006). Okul müdürlerinin insan kaynakları yönetimi işlevlerini yerine getirebilme yeterlikleri [Competencies of 
school principals to fulfill human resource management functions]. Milli Eğitim Dergisi [Journal of National Education], 170, 94-111.

Day, C. (1999). Developing teachers: The challenges of lifelong learning. $\mathrm{L}$ ondon: Falmer.

Djatmiko, I. W. (2010). The teaching strategies in vocational education in the knowledge era. International Seminar on Vocational Education and Training at Yogyakarta State University.

Duffield, S., Wageman, J., \& Hodge, A. (2013). Examining how professional development impacted teachers and students of U.S. history courses. The Journal of Social Studies Research, 37(2), 85-96.

Ekinci, A. (2010). Aday öğretmenlerin iş başında yetiştirilmesinde okul müdürlerinin rolü [The role of school principals in training prospective teachers at work]. Dicle Üniversitesi Ziya Gökalp Ĕgitim Fakültesi Dergisi [Journal of Dicle University Ziya Gökalp Faculty of Education], 15, 63-77.

Ekinci, E. (2015). Sinıf öğretmenlerinin mesleki gelişime ilişkin görüşleri (Mesleki gelişim modeli önerisi) [Classroom teachers' views on professional development (Professional development model proposal)]. (Unpublished master's thesis). Düzce University, Düzce, Turkey.

Elçiçek, Z. (2016). Öğretmenlerin mesleki gelişimine ilişskin bir model geliştirme çalışması [Study of developing a model for the professional development of teachers.]. (Unpublished doctoral thesis). Gaziantep University, Gaziantep, Turkey.

Fornell, C., \& Larcker, D. F. (1981). Evaluating structural equation models with unobservable variables and measurement errors. Journal of Marketing Research, 18, 39-50.

Gedik, S., \& Bellibas, M. S. (2015). Examining schools' distributed instructional leadership capacity: Comparison of elementary and secondary schools. Journal of Education and Training Studies, 3(6), 101-110.

Gözler, A., \& Özmen, F. (2008). Öğretmenlerin mesleki gelişiminde okul yöneticilerinin güdüleme rolleri [Motivational roles of school administrators in the professional development of teachers]. EJournal of New World Sciences Academy, 3(1), 66-79. 
Guskey, T. R. (2002). Professional development and teacher change. Teachers and teaching, 8(3), 381-391.

Gündüz, Y. \& Balyer, A. (2013). Gelecekte okul müdürlerinin gerçekleştirmeleri gereken roller [Roles that school principals should perform in the future]. Anadolu University Journal of Social Sciences, 13(3), 45-54.

Gürbüz, R., Erdem, E. \& Yıldırım, K. (2013). Başarılı okul müdürlerinin özellikleri [Characteristics of successful school principals]. Journal of Dicle University Ziya Gökalp Faculty of Education, 20, 167-179.

Gürer, G. T. (2017). Maarif müfettişlerinin ilkokul yöneticilerinin mesleki gelişimine katkisinın belirlenmesi [Determining the contribution of education supervisors to the professional development of primary school administrators]. (Unpublished master's thesis). Bal1kesir University, Balıkesir, Turkey.

Hardy, I. (2012). The politics of teacher professional development: Policy, research and practice. New York: Routledge.

Hooper, D., Coughlan, J., \& Mullen, M. (2008): Structural equation modelling: Guidelines for determining model fit. Electronic Journal of Business Research Methods, 6(1), 53-60.

Imhof, M. \& Picard, C. (2009). Views on using portfolio in teacher education. Teaching and Teacher Education, 25(1), 149-154.

İlğan, A. (2013). Öğretmenler için etkili mesleki gelişim faaliyetleri [Effective professional development activities for teachers]. Uşak University Journal of Social Sciences, Special Issue, 41-56.

Jöreskog, K. \& Sörbom, D. (1993). LISREL 8: Structural equation modeling with the SIMPLIS command language. Chicago, IL: Scientific Software International Inc.

Kennedy, M. M. (2016). How does professional development improve teaching? Review of educational research, 86(4), 945-980.

Kenny, D. A. \& McCoach, D. B. (2003). Effect of the number of variables on measures of fit in structural equation modeling. Structural Equation Modeling, 10(3), 333-351.

Kızılkaya, H. A. (2012). Öğretmenlerin mesleki gelişimlerinin mesleki gelişime yönelik tutumları ve iş doyumları bakımından incelenmesi üzerine bir araştırma [A study on the examination of teachers' professional development in terms of their attitudes towards 
professional development and job satisfaction]. (Unpublished master's thesis). Kirıkkale University, Kırıkkale, Turkey.

Korkmaz, İ. (2015). Öğretmenlerin mesleki gelişimlerinde okul yöneticileri ve denetmenlerin etkililiğinin incelenmesi [Investigation of the effectiveness of school administrators and supervisors in the professional development of teachers]. International Journal of Educational Sciences, 2(4), 55-64.

Kyriakides, L., Campbell, R. J., \& Gagatsis, A. (2000). The significance of the classroom effect in primary schools: An application of Creemers' comprehensive model of educational effectiveness. School Effectiveness and School Improvement, 11(4), 501-529.

Liu, S., Hallinger, P., \& Feng, D. (2016). Supporting the professional learning of teachers in China: Does principal leadership make a difference?. Teaching and Teacher Education, 59, 79-91.

Lysaght, Z., O’Leary, M., \& Ludlow, L. (2017). Measuring Teachers' Assessment for Learning (AfL) Classroom Practices in Elementary Schools. International Journal of Educational Methodology, 3(2), 103-115. doi:10.12973/ijem.3.2.103

MEB [Ministry of National Education]. (2016). PISA 2015 ulusal raporu. Ankara: MEB.

Muijs, D. \& Reynolds, D. (2000). School effectiveness and teacher effectiveness in mathematics: Some preliminary findings from the evaluation of the mathematics enhancement programme (primary). School Effectiveness and School Improvement, 11(3), 273-303.

Odabaşı, H. F. (2011). Öğretmenlikte mesleki gelişimin kuramsal ve kavramsal yapısı: Öğretmenlikte mesleki gelişim [Theoretical and conceptual structure of professional development in teaching: Professional development in teaching]. Eskişehir, Turkey: Anadolu University Publication, No: 1809.

OECD. (2009). Creating effective teaching and learning environments: first results from TALIS. Paris: OECD.

OECD. (2014). PISA 2012 results in focus: what 15-year-olds know and 2 what they can do with what they know. Paris: OECD.

Özdemir, S. M. (2016). Öğretmen niteliğinin bir göstergesi olarak sürekli mesleki gelişim [Continuous professional development as an 
indicator of teacher quality.]. Gazi Journal of Educational Sciences, 2(3), 233-244.

Özer, B. (2008). Öğretmenlik meslek bilgisi alanındaki gelişmeler [Developments in teaching professional knowledge.]. In A, Hakan (Ed.), Ögretmenlerin mesleki gelişimi [Professional development of teachers] (pp. 195-216). Eskişehir, Turkey: Anadolu University Faculty of Open Education Publications.

Postholm, M. B. (2012). Teachers' professional development: A theoretical review. Educational Research, 54(4), 405-429.

Richard, V., \& Bélanger, M. (2018). Accepting Research: Teachers' Representations of Participation in Educational Research Projects. International Journal of Educational Methodology, 4(2), 61-73. doi:10.12973/ijem.4.2.61

Rushton, S., Morgan, J., \& Richard, M. (2007). Teacher's Myers-Briggs personality profiles: Identifying effective teacher personality traits. Teaching and Teacher Education, 23, 432-441.

Sabuncuoğlu, O. (2006). A Study of the effects of model of teacher education and professional development on practising and prospective teachers of English in ELT at universities. (Unpublished doctoral thesis). Dokuz Eylül University, İzmir, Turkey.

Scheerens, J. (2010). Teachers' professional development: Europe in international comparison. Luxembourg: Office for Official Publications of the European Union.

Smith, C. \& Gillespie, M. (2007). Research on professional development and teacher change: Implications for adult basic education. Review of adult learning and literacy, 7(7), 205-244.

Smith, K. \& Tillema, H. (2001). Long-term influences of portfolios on Professional development. Scandinavian Journal of Educational Research, 45(2), 183-203.

Stein, M. K., \& Nelson, B. S. (2003). Leadership content knowledge. Educational evaluation and policy analysis, 25(4), 423448.

Stentoft, D. (2017). From saying to doing interdisciplinary learning: Is problem-based learning the answer? Active Learning in Higher Education, 18(1), 51-61.

Swart, F., Knèzic, D., Onstenk, J., \& Graaff, R.d. (2019). Evaluating and Improving Teacher Educators' Language-Oriented Performance in 
Content-Based Teaching. International Journal of Educational Methodology, 5(1), 71-86. doi:10.12973/ijem.5.1.71

Turan, S., Yıldırım, N., \& Aydoğdu, E. (2012). Okul müdürlerinin kendi görevlerine ilişkin bakış açıları [Perspectives of school principals about their duties]. Pegem Journal of Education and Instruction, 2(3), 63-76.

Uçar, Z. T. (2011). Öğretmen adaylarının pedagojik içerik bilgisi: Öğretimsel açılamalar [Teacher candidates' pedagogical content knowledge: Instructional explanations]. Turkish Journal of Computer and Mathematics Education, 2(2), 87-102.

Vangrieken, K., Meredith, C., Packer, T., \& Kyndt, E. (2017). Teacher communities as a context for professional development: A systematic review. Teaching and teacher education, 61, 47-59.

World Bank. (2011). Improving the quality and equity of basic education in Turkey challenges and options. Washington, DC: The World Bank.

Mehmet Fatih Karacabey is, $\mathrm{PhD}$, is an assistant professor in the Department of Educational Sciences, Harran University. His major research interests lie in the area of educational management and leadership, school principals' professional development, school dropout and educational policies.

\section{Contact Address:}

Harran University, Faculty of Education. E Blok - Osmanbey Campus. 63190 Şanlıurfa / TURKEY

E-mail: karacabeyakademi@gmail.com 